\title{
Determinants of fire intensity in working landscapes of an African savanna
}

\author{
Paul Laris ${ }^{1 *}$, Rebecca Jacobs ${ }^{1}$, Moussa Koné ${ }^{2}$, Fadiala Dembélé ${ }^{3}$ and Christine M. Rodrigue ${ }^{1}$
}

\begin{abstract}
Background: An often cited rule of savanna fire ecology is that early dry-season fires burn less intensely than late dry-season ones; however, few studies base their experimental design on the practices of fire managers in working landscapes. The objective of this research was to study the factors influencing fireline intensity, combustion, and patchiness for a West African savanna under common vegetation and land management practices. We conducted 97 experimental fires by selecting burn plots and seasonal timing (early, $n=33$; middle, $n=44$; or late, $n=20$ ) based on local practices in a typical working landscape. We collected data for biomass consumed, grass type, scorch height, speed of fire front, visual efficiency (patchiness), fire type, and ambient air conditions. We used multiple regression analysis to determine the key factors affecting fire intensity.

Results: Mean intensity was lowest for the middle season fires and highest for the late season fires. Minimum fire intensity increased over the fire season except for a sharp drop mid season, while maximum intensity progressively decreased. Seasonal values were highly variable. Fire intensity was moderately positively correlated with scorch height and more modestly correlated with visual efficiency, but only marginally correlated with combustion completeness. Average combustion completeness increased weakly as the dry season progressed. Intensity of backfires was determined primarily by seasonal timing and the associated ambient humidity and wind and, to a lesser extent, grass characteristics. Head-fire intensity was only feebly responsive to wind speed.

Conclusions: We found that, at the peak time of West African savanna burning, the intensity of fires decreased. Fire behaviors in working West African landscapes were more dependent on fire type and wind than seasonality. Finally, we found that fire intensity values were lower than those reported elsewhere due to the more representative conditions of the fire setting (under lower afternoon winds) and fuel loads (lower biomass on working landscapes). Future research should focus on the ecological impacts of fires set under such conditions on growth and death rates of savanna trees.
\end{abstract}

Keywords: Africa, combustion completeness, fire, intensity, Mali, savanna, seasonality, working lands

\footnotetext{
* Correspondence: paul.laris@csulb.edu

${ }^{1}$ Geography Department, California State University Long Beach, 1250

Bellflower Boulevard, Room PH1-210, Long Beach, California 90840, USA

Full list of author information is available at the end of the article
}

\section{Springer Open}

(c) The Author(s). 2020 Open Access This article is licensed under a Creative Commons Attribution 4.0 International License, which permits use, sharing, adaptation, distribution and reproduction in any medium or format, as long as you give appropriate credit to the original author(s) and the source, provide a link to the Creative Commons licence, and indicate if changes were made. The images or other third party material in this article are included in the article's Creative Commons licence, unless indicated otherwise in a credit line to the material. If material is not included in the article's Creative Commons licence and your intended use is not permitted by statutory regulation or exceeds the permitted use, you will need to obtain permission directly from the copyright holder. To view a copy of this licence, visit http://creativecommons.org/licenses/by/4.0/. 


\section{Resumen}

Antecedentes: Una regla frecuentemente citada en ecología de los fuegos de sabanas dice que los incendios que ocurren al inicio de la estación seca queman con menor intensidad que los que ocurren a fines de esta estación. Sin embargo, muy pocos estudios basan su diseño experimental en las prácticas que los gestores de fuego realizan en paisajes manejados. El objetivo de esta investigación fue estudiar los factores que influencian la intensidad de línea, la combustión y los parches en una sabana del oeste de África bajo prácticas comunes de manejo de vegetación y tierras. Condujimos 97 fuegos experimentales mediante la selección de parcelas quemadas y el período en que fueron hechas (tempranas, $n=33$; medias $n=44$; y tardías $n=20$ ), basados en prácticas locales en un paisaje de trabajo típico. Colectamos datos de biomasa consumida, tipo de pastos, altura de quemado, velocidad del frente de fuego, eficiencia visual (parcheado), tipo de fuego, y condiciones ambientales del aire. Usamos análisis de regresión múltiple para determinar los factores clave que afectan la intensidad del fuego.

Resultados: La intensidad promedio del fuego más baja ocurrió en la estación media y la más alta para los fuegos ocurridos en la estación tardía. La intensidad mínima del fuego se incrementó durante la temporada de fuego excepto por un brusco descenso en la estación media, mientras que la intensidad máxima decreció progresivamente. Los valores estacionales fueron altamente variables. La intensidad del fuego fue moderada- y positivamente correlacionada, con la altura de quemado, más modestamente correlacionada con la eficiencia visual, y solo marginalmente correlacionada con la combustión total. El promedio de la combustión total se incrementó semanalmente con el avance progresivo de la estación seca. La intensidad de fuegos en retroceso fue determinado primariamente por el transcurso de la estación y asociado a la humedad ambiente y los vientos, y en menor medida, a las características de los pastos. La intensidad de los fuegos frontales fue solo débilmente sensible a la velocidad de viento.

Conclusiones: Encontramos que, en el pico de la estación de fuegos en la sabana del oeste de África, la intensidad de los fuegos decrece. El comportamiento de los fuegos en los paisajes trabajados del oeste de África fue más dependiente de del tipo de fuego y del viento que de la estacionalidad en su ocurrencia. Finalmente, encontramos que los valores de intensidad fueron menores a los reportados en otros lugares debido a las condiciones más representativas de la implementación de las quemas (bajo vientos vespertinos más lentos) y cargas de combustible (menores cantidades de biomasa en paisajes trabajados). Investigaciones futuras deberían enfocarse en los impactos ecológicos de los fuegos establecidos en esas condiciones sobre el crecimiento y tasa de mortalidad de los árboles de esta sabana.

\section{Background}

A frequently cited rule of savanna fire ecology is that late dry-season (LDS) fires are more damaging to trees than early-dry season (EDS) fires. LDS fires are a major determinant of savanna vegetation because they prevent young trees from maturing (Sankaran et al. 2004; Higgins et al. 2007; Ryan and Williams 2011). Evidence in support of these principles is derived from experiments that began with the pioneering work of Aubréville (1953) in West Africa. The experiments were reproduced in many of the world's savannas with similar results (e.g., Furley et al. 2008). Importantly, many savanna fire experiments, especially the long-term studies, adopted Aubréville's earlylate fire convention in their experimental design (Laris et al. 2017; Table 1).

Recent analysis of burning finds that, while the fire season in West Africa is long, the majority of fires occur neither early nor late in the fire season; rather, they occur in the middle of the season with peak burning in early January (Laris et al. 2017). These new findings raise questions as to the impacts of more common midseason fires on tree-grass dynamics in savannas.
A second but equally important and often overlooked factor in the African context is fire direction or type (head-fire or back-fire). Fire direction is well documented as a major determinant of intensity in the broader fire literature (e.g., Cheney 1981), but has been understudied in savanna research. There have been few studies designed to test this variable. In one of the few detailed studies involving fire type in Africa, Trollope et al. (2002) found that head-fire (with the wind) intensity was seven times that of back-fires (against the wind) under the same conditions. For comparison, Williams et al. (1999) found that seasonality had about half this effect; LDS fires were about three and a half times as intense as EDS fires. Importantly, interview data from West Africa indicate that most fire users purposefully set back-fires for a plethora of uses, although, of course, fires may change direction and cause accidental head-fires.

Finally, a third factor not often considered in savanna fire studies is land management and, specifically, the different conditions found on working lands. By "working lands," we mean savanna lands that are occupied and worked by people, as opposed to areas managed as 
Table 1 Sample of African fire experiments, their locations, land management, and factors studied. For additional reviews of savanna fire studies globally, see Laris et al. 2017 and Furley et al. 2008. Fires set under low, medium, and high fire-weather conditions to modify intensity are marked with as asterisk (*). NA Not available

\begin{tabular}{|c|c|c|c|c|c|c|}
\hline Author & $\begin{array}{l}\text { Site location in } \\
\text { Africa, savanna type }\end{array}$ & $\begin{array}{l}\text { Precipitation } \\
(\mathrm{mm})\end{array}$ & $\begin{array}{l}\text { Land } \\
\text { management }\end{array}$ & Fire type & Fire timing & Study focus \\
\hline $\begin{array}{l}\text { Aubréville 1953; } \\
\text { Louppe et al. } \\
1995\end{array}$ & $\begin{array}{l}\text { Ivory Coast, Guinea } \\
\text { savanna }\end{array}$ & 1200 to 1250 & Reserve & NA & $\begin{array}{l}\text { Early: } 15 \\
\text { December } \\
\text { Late: } 1 \text { to } 15 \\
\text { May }\end{array}$ & $\begin{array}{l}\text { Long-term fire-timing effects on tree } \\
\text { cover }\end{array}$ \\
\hline $\begin{array}{l}\text { Trapnell 1959; } \\
\text { Chidumayo } 1997\end{array}$ & $\begin{array}{l}\text { Zambia, Miombo } \\
\text { savanna }\end{array}$ & 1170 & $\begin{array}{l}\text { Reserve } \\
\text { (felled trees) }\end{array}$ & NA & $\begin{array}{l}\text { Early: June to } \\
\text { July } \\
\text { Late: } \\
\text { September }\end{array}$ & $\begin{array}{l}\text { Long-term fire-timing effects on tree } \\
\text { growth and diversity }\end{array}$ \\
\hline $\begin{array}{l}\text { Ramsay and Rose- } \\
\text { Innes } 1963\end{array}$ & $\begin{array}{l}\text { Mali and Nigeria, } \\
\text { Soudan savanna }\end{array}$ & $1000+$ & Reserves & NA & Early and Late & $\begin{array}{l}\text { Long-term fire-timing effects on tree } \\
\text { cover }\end{array}$ \\
\hline $\begin{array}{l}\text { Afolayan and Ajayi } \\
1979\end{array}$ & Nigeria & 1100 & $\begin{array}{l}\text { National park } \\
\text { (some plots } \\
\text { grazed) }\end{array}$ & NA & Early and Late & $\begin{array}{l}\text { Tree density as function of fire timing } \\
\text { and grazing }\end{array}$ \\
\hline $\begin{array}{l}\text { Brookman- } \\
\text { Amissah et al. } \\
1980\end{array}$ & $\begin{array}{l}\text { Ghana, Guinea } \\
\text { savanna }\end{array}$ & 1100 & $\begin{array}{l}\text { Forest reserve } \\
\text { (felled trees) }\end{array}$ & NA & $\begin{array}{l}\text { Early: } \\
\text { November } \\
\text { Late: April }\end{array}$ & $\begin{array}{l}\text { Long-term fire-timing effects on tree } \\
\text { growth }\end{array}$ \\
\hline Eldroma 1984 & Uganda & 880 & $\begin{array}{l}\text { National park } \\
\text { (some plots } \\
\text { grazed) }\end{array}$ & NA & $\begin{array}{l}\text { Early: June } \\
\text { Late: August }\end{array}$ & $\begin{array}{l}\text { Effects } s \text { of fire timing and fuel load on } \\
\text { grasses and small trees }\end{array}$ \\
\hline $\begin{array}{l}\text { Trollope 1987; } \\
\text { Trollope et al. } \\
2002\end{array}$ & $\begin{array}{l}\text { South Africa, Kruger } \\
\text { (multiple studies) }\end{array}$ & 450 to 750 & National park & $\begin{array}{l}\text { Head- and } \\
\text { back-fires }\end{array}$ & Multiple dates & $\begin{array}{l}\text { Fire intensity and severity, effects on } \\
\text { juvenile trees }\end{array}$ \\
\hline $\begin{array}{l}\text { Govender et al. } \\
2006\end{array}$ & South Africa, Kruger & 450 to 750 & National park & NA & Multiple dates & $\begin{array}{l}\text { Fire intensity as function of fuel } \\
\text { moisture content }\end{array}$ \\
\hline Higgins et al. 2007 & South Africa, Kruger & 450 to 750 & National park & NA & $\begin{array}{l}\text { Early: April; } \\
\text { Late: August } \\
\text { Wet season }\end{array}$ & $\begin{array}{l}\text { Long term effects of fire timing and } \\
\text { frequency on tree density and biomass }\end{array}$ \\
\hline $\begin{array}{l}\text { Savadogo et al. } \\
2007\end{array}$ & $\begin{array}{l}\text { Burkina Faso, Soudan } \\
\text { savanna }\end{array}$ & 850 & $\begin{array}{l}\text { State forest } \\
\text { (some plots } \\
\text { grazed) }\end{array}$ & $\begin{array}{l}\text { Head- and } \\
\text { back-fires }\end{array}$ & $\begin{array}{l}\text { Early: } \\
\text { November to } \\
\text { December }\end{array}$ & $\begin{array}{l}\text { Effects of fuel load and weather on fire } \\
\text { intensity }\end{array}$ \\
\hline Furley et al. 2008 & Zimbabwe, Miombo & 900 & Reserve & NA & Late & $\begin{array}{l}\text { Long-term fire frequency effects on tree } \\
\text { cover }\end{array}$ \\
\hline $\begin{array}{l}\text { Ryan and Williams } \\
2011\end{array}$ & $\begin{array}{l}\text { Mozambique, } \\
\text { Miombo }\end{array}$ & 850 & Reserve & $N A^{*}$ & $\begin{array}{l}\text { Late: } \\
\text { September }\end{array}$ & Fire intensity and severity \\
\hline Devine et al. 2015 & South Africa, Kruger & 450 to 750 & National park & NA & Late: August & $\begin{array}{l}\text { Long-term fire frequency effects on tree } \\
\text { growth and cover }\end{array}$ \\
\hline Smit et al. 2016 & South Africa, Kruger & 450 to 750 & National park & $N A^{*}$ & $\begin{array}{l}\text { Early: June to } \\
\text { July } \\
\text { Late: } \\
\text { September }\end{array}$ & $\begin{array}{l}\text { Fire timing and fuel moisture effects on } \\
\text { intensity }\end{array}$ \\
\hline N'Dri et al. 2018 & $\begin{array}{l}\text { Ivory Coast, Guinea } \\
\text { savanna }\end{array}$ & 1200 & Reserve & Head-fire & $\begin{array}{l}\text { Early: } \\
\text { November } \\
\text { Middle: January } \\
\text { Late: March }\end{array}$ & $\begin{array}{l}\text { Fire timing and fuel moisture effects on } \\
\text { intensity }\end{array}$ \\
\hline
\end{tabular}

reserves or field stations (e.g., Charnley et al. 2014); the latter are most often used in fire research (Table 1). The biomass (fuels) and fuel conditions in working landscapes are a function of land use practices including rotational agriculture and animal grazing, and can differ significantly from those found on non-working lands, which can affect fire intensity.

Fire intensity is a critical determinant of fire's impact on vegetation and is the most frequently used variable in fire ecology studies. A common measure is Byram's fireline intensity (hereafter, intensity), which is a function of the heat of combustion, the amount of fuel consumed, and the rate of spread (Byram 1959). Intensity is largely controlled by fuel load, moisture content, and weather conditions and is strongly related to wind direction (Cheney et al. 1998). In head-fires, winds force flames into unburned material ahead of the fire front, resulting in more efficient preheating and drying and greater rates 
of spread (Cheney 1981). Head-fires are also thought to have a greater effect on trees than on grasses because flames are taller, thus heat is released closer to the tree growing points in the canopy. Therefore, it's surprising that many studies on African savanna fires fail to note the wind direction relative to the fires (e.g., Aubréville 1953; Biggs et al. 2003; Smit et al. 2016; N'Dri et al. 2018; Table 1). Other studies simply state that the goal of the fire was to achieve as high a temperature as possible (Furley et al. 2008) or to prove the damaging impacts of fire (Biggs et al. 2003).

Two additional factors that are important for determining the effects of savanna fires are combustion completeness and patchiness (referred to here as visual efficiency). Evidence suggests that EDS fires burn more patchily and consume less biomass than later fires, while they also tend to have a lower combustion efficiency due to higher fuel moisture levels and fuel composition (fuel moisture is higher in EDS while leaf litter increases later in the season). Patchy early burning is known to be an effective approach for reducing total burned area; however, the lower combustion efficiency associated with early burning theoretically causes higher emissions of methane, an important greenhouse gas. As such, there is a critical need to understand how fire patchiness and combustion efficiency vary by fire type and season.

The objectives of this research were to examine the factors influencing fire intensity, combustion completeness, and visual efficiency for two working savannas. We tested the hypotheses that fire intensity and combustion completeness increase over the course of a dry season. The burning regimes studied here, which are determined by such factors as seasonality, time of day (ambient weather), fire type (with or counter to the wind), grass type, and woody vegetation cover, were all selected to reflect local practices to the extent possible.

\section{Methods}

To study the impacts of a variety of variables on fire intensity, we conducted 97 successful experimental fires over a two-year period (January 2014 through March 2016) at two mesic savanna sites in West Africa: Tabou and Faradiele, Mali. Success here means that data were collected on all variables of interest; another 62 experiments were conducted but did not yield complete records (typically due to equipment failure). Thirty-three of these 97 were conducted in the early season between November and December, with 19 of these being headfires and 14 back-fires. Forty-four were conducted in the mid-season of January, 19 as head-fires and 25 as backfires; another 20 were carried out in the late season (February and March), with 9 head-fires and 11 backfires. These experiments distributed test fires in both the early and late fire season to evaluate expectations from previous literature, as well as in the mid-season to align with local practice.

\section{Study area}

The study areas were located in the Sudanian savanna of southern Mali (Fig. 1). The climate is divided into two seasons: a wet period from approximately June through October, and a dry season from November through May. The wet and dry pattern follows the movement of the Intertropical Convergence Zone (ITCZ) and the dry season begins slightly earlier and ends later in the northern part of the study area. There is a cool dry period from approximately November through February, and a hot dry period from March through May. This distinction is important for fires because weather in the cool season is dominated by the dry, dusty Harmattan wind blowing from the Sahara, which desiccates vegetation and creates unique fire weather. Monthly temperature and precipitation norms were selected from Bamako (latitude: $12.64^{\circ}$, longitude: $-8.00^{\circ}$ ) and Bougouni (latitude: $11.42^{\circ}$, longitude: $-7.47^{\circ}$ ), urban areas located close to each site, for which there is good climate data. The mean annual rainfall is $991.2 \mathrm{~mm}$ for Bamako and $1176.8 \mathrm{~mm}$ for Bougouni (Henry 2011). The fire season follows the rains and typically runs from November through April, with a peak in burning occurring in late December and early January (Laris et al. 2016).

The vegetation is southern Sudanian savanna and is predominantly composed of a mixture of grasses, trees, and shrubs arranged in a complex mosaic. The landscape heterogeneity is a function of underlying soil and hydrology, as well as its agricultural use, the combination of which produces unique patterns of land cover (Duvall 2011; Laris 2011). Except for the intensively cultivated areas, a near-continuous layer of tall (over $1 \mathrm{~m}$ in height) perennial grasses (principally Andropogon gayanus Kunth, Hyparrhenia dissoluta Clayton, Cymbopogon giganteus Ciov., and Schizachyrium pulchellum Stapf) covers the more fertile soils, although there are pockets where the tree canopy is closed and there is little grass cover. The land cover in settled areas has been significantly modified. Perennial grasses are less common and large portions of the landscape are covered by annual grasses, particularly Andropogon pseudapricus Stapf and Pennisetum pedicellatum Trin., with some scattered trees. Ferricrete outcrops on hard pan also cover considerable areas. Vegetation on such gravelly soils is dominated by short, annual grasses (principally Loudetia togoensis Hubb but also Andropogon pseudapricus Stapf; Laris 2011).

\section{Plot design}

Plots were selected to represent an array of savanna vegetation types dominated by different grass species. To 


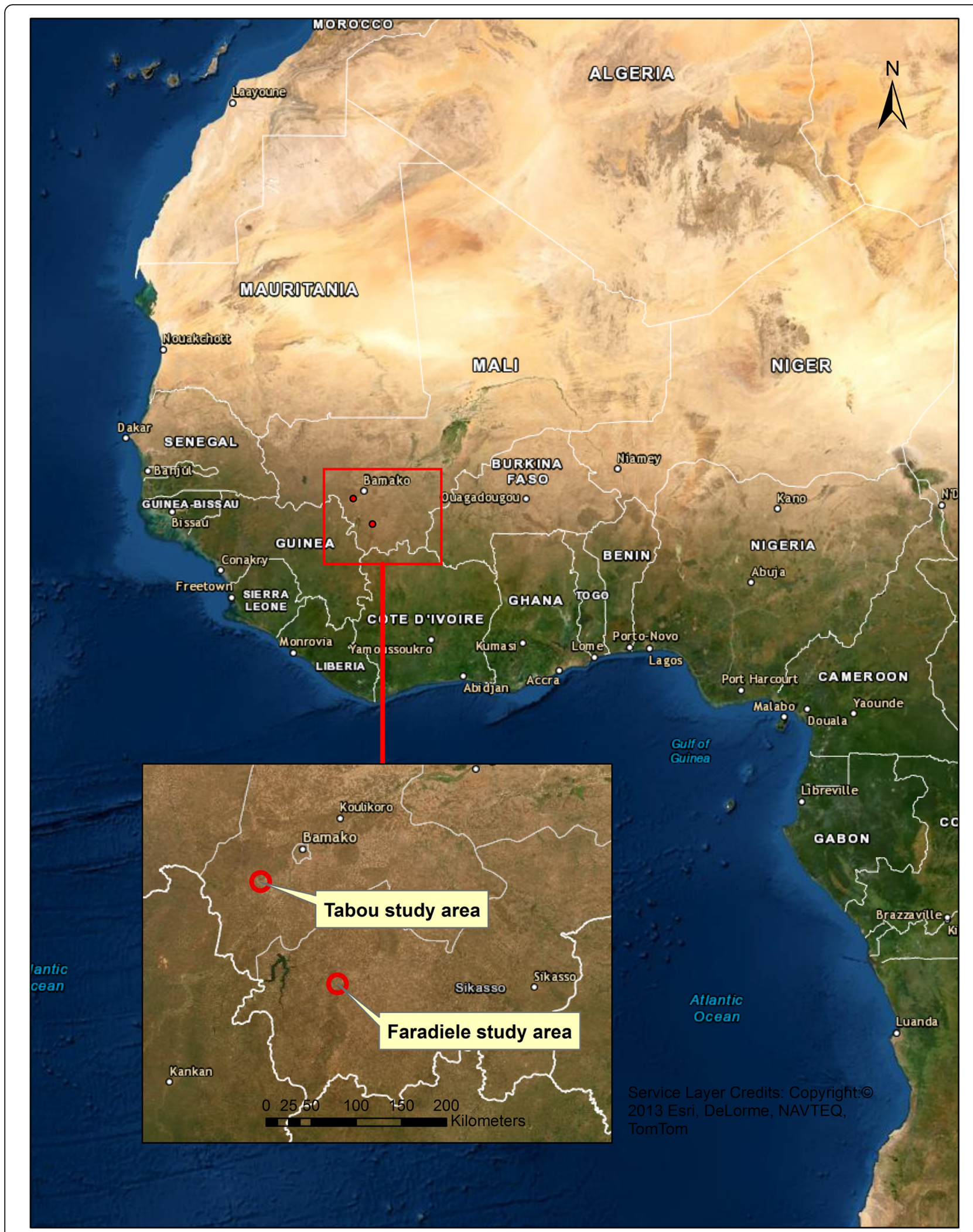

Fig. 1 Location of the research sites in southern Mali, Africa, used for our seasonal fire intensity study, from 2014 to 2016 
aid in the selection of the burn plots, we used a longterm fire database (Laris 2011) to select sites known to burn regularly at a specific time of year. We divided the sites into plots of $10 \times 10$ meters and applied head-fire and back-fire treatments for three different periods. We selected $10 \times 10 \mathrm{~m}$ plots (a rather small area) for two reasons: first, we were primarily interested in studying back-fires, which take little time and space to develop; and second, we wanted to study the effects of fires on a wide variety of vegetation types under a variety of local conditions. In addition, because most fires were set under light winds (in accordance with local practices), even head-fires developed a steady flaming front within a short distance. Finally, we note that, in many cases, West African burning regimes create a patch-mosaic pattern of small and fragmented burns especially in the earlier parts of the fire season. A line-source ignition was used for each case by setting fire with a torch to a ten-meter edge. Ignition generally took less than ten seconds and a flaming fire front most often developed within a few seconds.

Malians typically set back-fires and, although our objective was to replicate local practice, we paired backfires with head-fires to compare results with existing literature that emphasizes head-fires. Fire timing was set according to the historical pattern of burning, with EDS set in November through December, middle- dry season (MDS) fires in January, and LDS fires in late February and March. In general, people set fires just prior when grasses are completely dry (Laris 2002; Le Page et al 2010). They begin burning early on plots of short annual grasses, which desiccate quickly following the end of the rains. They then burn taller annuals and some perennials following the harvest in mid season. Late-season fires burn a variety of grass species, nearly all of which are very dry (Laris 2011). When possible, we conducted multiple burns per site to account for plot-level heterogeneity. Plots at each site were located near each other with attention paid to maintaining consistency in grass type and woody cover. Back-fire plots were located adjacent and downwind from head-fire plots. They were burned first to create suitable fire-breaks for head-fires.

\section{Data collection}

Data on the following variables were collected in the field: fire season, average plot biomass, grass and litter percentage of biomass, biomass consumed, fuel moisture, grass species, wind speed, ambient humidity, temperature, fire type, time of day, fire duration, scorch height, visual burn efficiency (a measure of patchiness), and savanna type. Fuel load (plot biomass) was measured in each of the experimental plots by delineating three representative pre-fire quadrats of $1 \mathrm{~m} \times 1 \mathrm{~m}$. Grasses were cut at the base using a scythe, weighed with an electronic balance, and averaged. When present, leaf litter was weighed separately. Most grasses burned were fully cured; however, for those that were not, a sample was cut and weighed wet, then dried and reweighed to determine the cure rate, which was taken as the average for the plot. Fuel moisture content was then calculated for each plot using the method developed by Viney (1991). Vegetation characteristics including grass type (annual or perennial), grass species, and leaf height were recorded for each site.

A Kestrel 5500 Weather Meter (KestrelMeters.com, Boothwyn, Pennsylvania, USA) station was used to measure wind speed, ambient humidity, and temperature during the burning of each plot. We recorded values every five seconds and these were averaged for each burn time. The weather station was placed approximately 10 meters up-wind from each experimental plot, approximately $1.5 \mathrm{~m}$ off the ground in an open area. Wind direction relative to the direction of each fire was recorded.

Ignition time was noted and each fire was timed until the flaming front reached the end of the 10-meter plot. All fires were also videotaped. The majority of fires were set in late afternoon, under low wind conditions in accordance with local practice. Post fire, ash was gathered manually and any unburned materials were weighed for areas similar in composition to the $1 \mathrm{~m} \times 1 \mathrm{~m}$ pre-fire quadrats to determine the amount of biomass consumed. Scorch height was averaged for each plot by measuring the height of scorch marks on several small trees. Visual efficiency-the percentage of total biomass burned-was estimated and agreed upon by two observers. As our goal was to understand drivers for fireline intensity, analysis focused on a subset of eight of these variables, which are scalar or binary, selected to reduce multi-collinearity: early, middle, and late seasons (two dummy variables for early and middle seasons); wind speed $\left(\mathrm{m} \mathrm{s}^{-1}\right)$; ambient temperature $\left({ }^{\circ} \mathrm{C}\right)$; relative humidity (\%); annual versus perennial vegetation (binary); and grass as a percentage of total biomass.

\section{Analysis}

To quantify intensity we used Byram's fireline intensity, which is defined as

\footnotetext{
${ }^{1}$ We used the value of $20000 \mathrm{~kJ} \mathrm{~kg}^{-1}$ following Williams et al. (1998: 230), who noted: "Given the range and lack of consistency between studies in the value of $\mathrm{H}$, and, in the view of the authors, the misleading precision implied by values rounded to the nearest $100 \mathrm{~kJ} \mathrm{~kg}^{-1}, 20,000 \mathrm{~kJ} \mathrm{~kg}^{-1}$ is within the range of reported vales, and is easy and convenient to apply."

${ }^{2}$ We note that, while a portion of the unburned material was likely mineral- as opposed to carbon-based ash, the majority of the unburned fuels were in the form of grass and leaf remains.
} 


$$
I=H w r,
$$

where $I$ is Byram's fireline intensity $\left(\mathrm{kW} \mathrm{m}^{-1}\right), H$ is the net low heat of combustion $\left(\mathrm{kJ} \mathrm{kg}^{-1}\right), w$ is the fuel consumed in the active flaming front $\left(\mathrm{kg} \mathrm{m}^{-2}\right)$, and $r$ is the linear rate of fire spread $\left(\mathrm{m} \mathrm{sec}^{-1}\right)$. The net low heat of combustion $(H)$ was selected following Williams et al. (1998) with $20000 \mathrm{~kJ} \mathrm{~kg}^{-1}$ as an appropriate value for comparison with other savanna fire studies. ${ }^{1}$ Fuel moisture content for the cured fuels was calculated using the method developed by Viney (1991) based on McArthur (1967) for savanna fuels:

$$
m=5.658+(0.04651 H)+\left[\frac{\left(0.0003151 H^{3}\right)}{T}\right]-\left(0.1854 T^{0.77}\right),
$$

where $H$ is relative humidity and $T$ is ambient temperature at the time of the burn. Dry biomass weight was then calculated by subtracting the fuel moisture content from the wet biomass weight.

The amount of fuel consumed was calculated by subtracting the average ash and unburned fuels remaining in three quadrats per plot from the pre-fire dry biomass weight. $^{2}$ Variable $r$ (rate of spread, m) was derived from the plot dimensions $(10 \times 10 \mathrm{~m})$ and the time it took for the base of the first flaming front to reach the end of the plot. Byram's I, calculated for each of the experimental fires, was the dependent variable for all analyses.

We calculated fireline intensity for 97 samples possessing all eight of the variables selected for analysis. We transferred the data to IBM Statistical Package for the Social Sciences (SPSS; https://www.ibm.com/analytics/ spss-statistics-software) and Palaeontological Statistics 3 (Hammer et al. 2001) software for correlation and regression analysis, difference of means $t$-tests, and oneway ANOVA to facilitate understanding of the relationships among variables and to model the main drivers of variation in fireline intensity. We set a conventional standard for significance to minimize the risk of false positives $(P=0.05)$. Given that circumstances necessarily limited the number of burns, increasing the risk of false negatives, we computed achieved post-hoc power $(1-\beta)$ using G*Power (Faul et al. 2009).

To analyze our data, we ran cross correlations of all eight variables and then three multiple regression models-Enter, Backward, and Forward (McDonald 2014) - using Byram's fireline intensity as the dependent variable for all models. The Enter method of multiple regression offered information on the associations of all variables with the dependent variable in interaction with one another and allowed evaluation of multi-collinearity. Our goal, however, was to identify core drivers of fireline intensity as they interact with one another, so we applied the Backward and Forward selection methods to simplify the
Enter model. There were seven independent variables: wind speed, relative humidity, ambient temperature, grass type (annual or perennial), grass percentage of biomass and season (early, middle, and late, converted into two dummy variables: early and middle).

Variables were assessed for conformity to the needs of regression analysis: level of measurement, linearity, homoscedasticity, normality, and residuals for normality. Four of the variables were scalar, grass type was a binary (annual $=0$ and perennial $=1$ ), and season made up two dummy variables. All scalar variables had third moment skew and fourth moment excess kurtosis under $1.00( \pm)$ except the dependent variable, which was markedly rightskewed $(+2.540)$ and platykurtic $(+3.792)$. This was corrected by log-transforming Byram's fireline intensity, which was then used in all further analyses. All scalar independent variables displayed linear associations with the logged Byram's fireline intensity, most with rough balance of data along the least-squares line (Fig. 2). After regression modeling was complete, we utilized scatterplots of standardized predicted values against standardized residuals with fitted LOESS lines, as well as normal P-P plots (McDonald 2014), to evaluate the normality and heteroscedasticity of the residuals, and these affirmed the conformity of our data with the needs of regression modeling.

Independent variables were also evaluated for multicollinearity to optimize model specification. This was done through the Enter method of multiple regression using the collinearity diagnostics option in SPSS, and all variables showed tolerances greater than 0.250 and variance inflation factors less than 4. Multi-collinearity is, thus, unlikely to destabilize regression results.

After this pre-processing, model building was done with multiple linear regression using both the Backward and the Forward approaches to simplification. First, these were performed with all 97 records. Second, they were repeated for the 50 back-fires and, third, for the 47 head-fires in the sample. The records:variables ratio of this dataset (for all 97 records and seven independent variables, the subjects to variables ratio was 13.9:1; for the 50 back-fires it was 7.1:1, and for the 47 head-fires it was 6.7:1) approached the cusp of what is recommended for multiple regression models (Austin and Steyerberg 2015), which could limit the robustness of the analysis by introducing small sample effects and associated uncertainties. A second potential limitation of these data was the possibility for imprecision in the measurements; chaotic fire behavior in field conditions may make precise observations challenging.

\section{Results}

Fire characteristics

The mean plot characteristics for biomass and weather conditions demonstrate the importance of the inclusion 

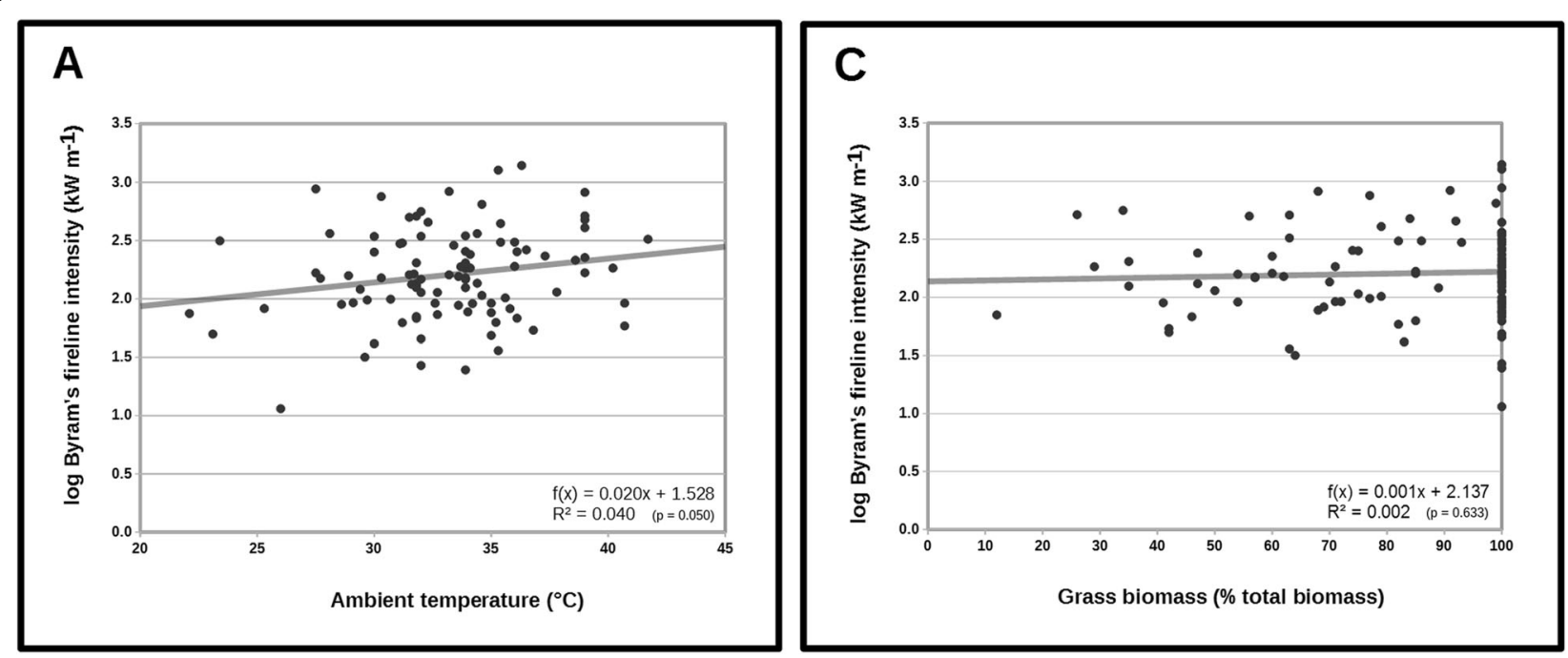

\section{B}

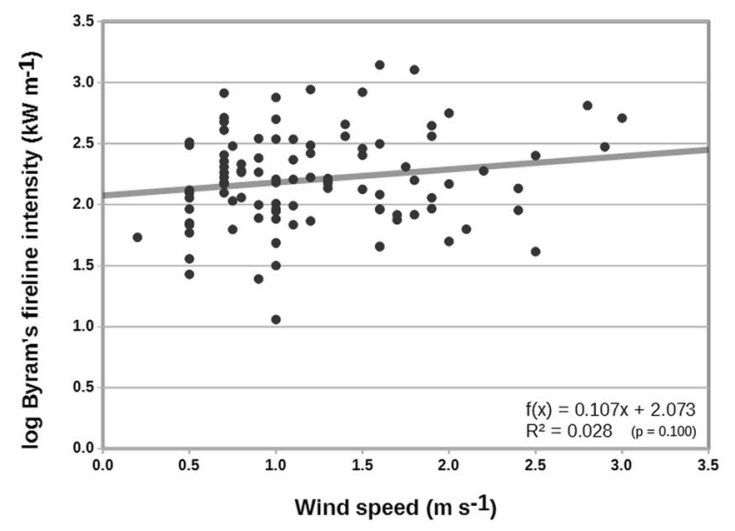

D

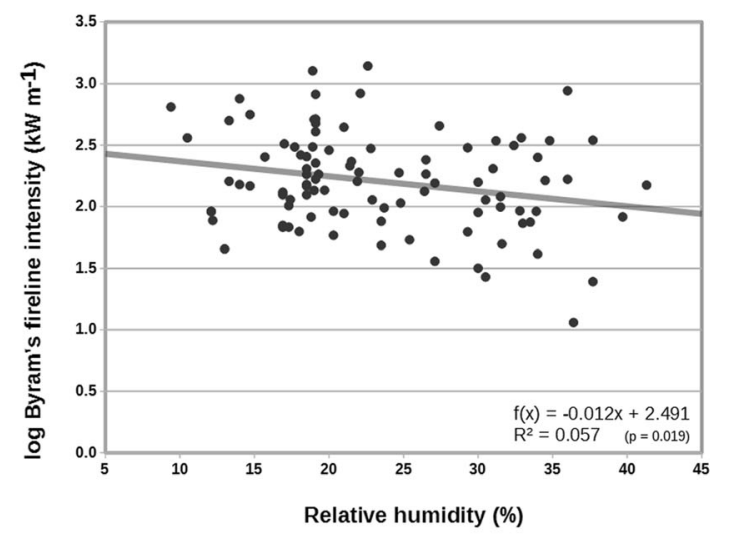

Fig. 2 Scatterplots and linear regressions of all non-binary independent variables-(A) ambient temperature $\left({ }^{\circ} \mathrm{C}\right),(\mathbf{B})$ wind speed $\left(\mathrm{m} \mathrm{s}^{-1}\right),(\mathbf{C})$ grass dominance (\% total biomass), and (D) relative humidity (\%) - with the log of Byram's fireline intensity $\left(\mathrm{kW} \mathrm{m}^{-1}\right)$ for seasonal fire intensity experimental plots, as recorded at the time and site each fire was set in Tabou and Faradiele villages, Mali, Africa, from 2014 to 2016

Table 2 Mean plot characteristics of the seasonal fire intensity field study conducted in Mali, West Africa, from 2014 to 2016 , by study period (early season, middle season, and late season). Standard deviations are in parentheses

\begin{tabular}{lrrr}
\hline Mean plot characteristics & Early season & Middle season & Late season \\
\hline Biomass $\left(\mathrm{t} \mathrm{ha}{ }^{-1}\right)$ & $4.07(1.31)$ & $4.99(2.08)$ & $4.39(2.11)$ \\
Dry biomass consumed $\left(\mathrm{t} \mathrm{ha}^{-1}\right)$ & $3.88(1.25)$ & $4.79(2.01)$ & $4.23(2.03)$ \\
Grass biomass (\%) & $90.39(18.68)$ & $75.25(23.74)$ & $78.30(22.98)$ \\
Fuel moisture (\%) & $4.81(0.57)$ & $4.59(0.73)$ & $3.65(0.26)$ \\
Temperature $\left({ }^{\circ} \mathrm{C}\right)$ & $32.45(3.37)$ & $32.03(3.32)$ & $36.80(3.28)$ \\
Relative humidity (\%) & $29.62(5.12)$ & $20.64(7.92)$ & $19.34(1.48)$ \\
Wind speed $\left(\mathrm{m} \mathrm{s}^{-1}\right)$ & $1.16(0.55)$ & $1.45(0.60)$ & $0.85(0.53)$ \\
\hline
\end{tabular}


Table 3 Mean fire characteristics of the seasonal fire intensity field study conducted in Mali, West Africa, from 2014 to 2016 , by study period (early season, middle season, and late season). Standard deviations are in parentheses

\begin{tabular}{lrrr}
\hline Mean fire characteristics & Early season & Middle season & Late season \\
\hline Spread rate $\left(\mathrm{m} \mathrm{s}^{-1}\right)$ & $0.031(0.02)$ & $0.028(0.03)$ & $0.034(0.01)$ \\
Burn time $(\mathrm{s})$ & $599.7(488)$ & $736.6(591)$ & $357.6(172)$ \\
Scorch height $(\mathrm{m})$ & $1.39(0.52)$ & $1.31(0.68)$ & $1.70(0.63)$ \\
Visual efficiency $(\%)$ & $85.33(12.44)$ & $92.32(11.42)$ & $99.20(1.06)$ \\
Combustion completeness (\%) & $85.05(12.50)$ & $85.21(11.68)$ & $93.07(3.49)$ \\
\hline
\end{tabular}

of the mid season (Table 2). Average temperature generally increased over the dry season, but a dip of $0.4{ }^{\circ} \mathrm{C}$ appeared in mid season, which is an established phenomenon in West African climates. Average humidity decreased monotonically as the dry season progressed, but the mid-season humidity was considerably more variable than in the early and especially in the late seasons because of the unpredictability in the retreat of the Intertropical Convergence Zone. Calculated fuel moisture content declined over the course of the dry season from a mean of $4.81 \%$ in the EDS, to $4.59 \%$ and $3.65 \%$ in the MDS and LDS respectively; however, when combined with the measured mean cure rates for wet grasses, the total fuel moisture was $8.40 \%$ in the EDS, $12.04 \%$ in the MDS, and $3.65 \%$ in the LDS. Mean wind speed peaked mid season as the Harmattan winds came in, although the wind speeds were relatively low-classified as a light breeze on the Beaufort scale. In terms of biomass, percent grass of the total plot biomass was greatest in the early season, while the total biomass (total fine fuels; grasses and leaves) was higher later in the dry season, reflecting an increase in the amount of leaf litter as the dry season progressed. The increase in dry biomass also reflects the changes in species types that were burned-the taller perennials often burn later in the dry season. Some perennials are too moist to burn during the early months of the dry season and burn less completely in the mid season due to higher moisture content.

The characteristics of the fires also varied by period (Table 3). The average visual efficiency and the average combustion completeness both increased monotonically as the dry season progressed, both showing greater variability in the early and mid seasons and much less variability in the late season when near totality was achieved. Scorch height and burn time (two factors closely related to intensity) showed a slightly different pattern. The middle season had the lowest average values for scorch height and highest variability, while burns took substantially longer and were more variable in the middle season. This was in spite of higher wind speeds, perhaps reflecting the slight drop and greater variability in temperatures mid season.

While the minimum intensity increased nonmonotonically over the fire season, dipping in mid season, the maximum intensity decreased monotonically (Table 4). The standard deviation of the seasonal intensity values indicates high variability, especially in earlyseason fires. The high variation in intensity values with respect to mean values usually reflects the wide variety of fuel, weather, and fire conditions. Calculated intensity values ranged from 10.82 to $1341.45 \mathrm{~kW} \mathrm{~m}^{-1}$ for all plots. This variable was highly right skewed and was logged for regression analysis. Intensity was positively and significantly correlated to scorch height $(\mathrm{R}=0.693$, $P<0.001)$, visual efficiency $(\mathrm{R}=0.366, P<0.001)$, and combustion completeness $(\mathrm{R}=0.262, P=0.009)$.

\section{Regression analysis for intensity}

Running three multiple regression types to predict Byram's fireline intensity (logged) on all fires at all seasons produced three very different models (Table 5). In

Table 4 Intensity values ( $\mathrm{kW} \mathrm{m}^{-1}$ ), including logged values, by study period (early season, middle season, and late season) for all fires, from the seasonal fire intensity field study conducted in Mali, West Africa, from 2014 to 2016

\begin{tabular}{|c|c|c|c|c|}
\hline \multirow[b]{2}{*}{ Study period } & \multicolumn{4}{|c|}{ Intensity $\left(\mathrm{kW} \mathrm{m}^{-1}\right)$} \\
\hline & Minimum & Maximum & Mean & Standard deviation \\
\hline Early season & 32.43 & 1341.45 & 223.82 & 259.58 \\
\hline Early season logged & 1.37 & 3.13 & 2.15 & 0.42 \\
\hline Middle season & 10.82 & 1225.99 & 208.83 & 226.91 \\
\hline Middle season logged & 1.03 & 3.09 & 2.14 & 0.39 \\
\hline Late season & 55.45 & 801.31 & 276.69 & 213.87 \\
\hline Late season logged & 1.75 & 2.90 & 2.34 & 0.30 \\
\hline
\end{tabular}


Table 5 Fire regression model statistics for 97 fires from the seasonal fire intensity field study conducted in Mali, West Africa, from 2014 to 2016. F and Sig F are F-test and significance, respectively, and $\# \chi$ is the number of independent variables in the model. $Y=$ $\log$ fireline intensity; $X_{1}=$ wind speed $\left(\mathrm{m} \mathrm{s}^{-1}\right) ; X_{2}=$ humidity; $X_{3}=$ ambient temperature $\left({ }^{\circ} \mathrm{C}\right) ; X_{4}=$ mid-season dummy variable; $X_{5}=$ grass percentage of biomass; $X_{6}=$ early-season dummy variable; $X_{7}=$ annual and perennial binary variable

\begin{tabular}{|c|c|c|c|c|c|c|c|}
\hline Model & $\mathbf{R}$ & $R^{2}$ adj & $\mathrm{F}$ & Sig $F$ & Power & $\# \chi$ & Model variables and constants \\
\hline Enter & 0.432 & 0.122 & 2.914 & 0.009 & 0.662 & 7 & \\
\hline Backward & 0.421 & 0.150 & 6.661 & $<0.001$ & 0.895 & 3 & $Y=2.52+0.20 X_{1}-0.20 X_{2}-0.26 X_{4}$ \\
\hline Forward & 0.238 & 0.047 & 5.711 & 0.019 & 0.561 & 1 & $Y=2.49-0.01 X_{2}$ \\
\hline
\end{tabular}

the Enter method, wind speed, relative humidity, and the mid-season dummy variable showed significant associations with logged fireline intensity in combination with the other six predictors $(P=0.006,0.030$, and 0.049 , respectively). The overall model was significant $(P=0.009)$ but showed a weak effect size $\left(R^{2}\right.$ adj $\left.=0.122\right)$. While significant, post-hoc power analysis suggested that the sample size was not fully adequate for working with seven predictor variables $(1-\beta=0.662)$. The Backward approach built five models using the default $\mathrm{P}$-in of 0.05 and P-out of 0.10 , resulting in the retention of three independent variables: wind speed, relative humidity, and the mid-season dummy variable. The final model was very highly significant $(P<0.001)$ and, with the reduction in predictors, the sample size was up to the task of detecting an improved but still weak effect $\left(R^{2}\right.$ adj $=0.150$ ) with $1-\beta$ at 0.895 . The Forward method was unable to move past one independent variable, relative humidity, using the $\mathrm{P}$-in default. The result showed a trivial effect $\left(R^{2}\right.$ adj $\left.=0.047\right)$ and inadequate power $(1-\beta$ $=0.561)$, although the model was significant $(P=0.019)$. Since tolerances exceeded 0.25 for all variables, multicollinearity was an unlikely source for the disparity in results, which could instead reflect instabilities associated with inadequate power or with the inclusion in the complete data set of fundamentally very different firing practices.

The uniqueness of head- and back-fires is demonstrated by the results of some basic statistics from our field trials. The mean head-fire intensity was $342.3 \mathrm{~kW} \mathrm{~m}^{-1}$, nearly three times the back-fire mean intensity of $120.4 \mathrm{~kW} \mathrm{~m}^{-1}$ ( $t$-test of the significance of differences yielded $P<0.001$ ). Head-fires also displayed far more variation in intensity values, indicated by the standard deviation of 299.01, in comparison with the standard deviation of 82.56 displayed by back-fires (Table 6). A one-way ANOVA was applied to mean log intensities in the early-, middle-, and late-season groups and found no significant differences $(P=0.158$ for logged fireline intensity). Thus, we found that, under typical West African burning conditions, fireline intensity does not differ much with season when compared to the differences found between headfires and back-fires.

The head-fires dataset did not produce significant results when all seven predictors were entered. The ensemble of drivers produced an effect too feeble for the model to detect with only 47 records. Model simplification through automatic selection Forward and Backward was able to detect the faint signal of only one independent variable (wind speed) as a driver of fireline intensity in head-fires with the available dataset. Head-fires, typically cited in previous attempts to characterize firing of African savanna, are nearly unpredictable functions of wind behavior.

All back-fire multiple regression models, on the other hand, produced dramatically better results than their head-fire equivalents. All three back-fire models were significant at $P=0.01$ or less (Table 7 ), and their effect sizes ranged from weak to moderate (adjusted $R^{2}$ ranged from 0.233 to 0.301 ), exceeding those of the Forward models by 2.5 to 4.0 times. For effects in this range, achieved power ( $1-\beta$ from 0.710 to 0.854 ) indicated that the number of fires that the field team was able to set was enough to detect these effects. Relative humidity emerged as the single explanatory variable shared by the Backward and Forward models. There was a difference in the two models' other retained predictors, however. The Backward approach added three other variables (wind speed and the two season dummy variables) not

Table 6 Head-fire regression model statistics from the seasonal fire intensity field study conducted in Mali, West Africa, from 2014 to 2016. F and Sig F are F-test and significance, respectively, and $\# \chi$ is the number of independent variables in the model. $Y=l o g$ fireline intensity; $X_{1}=$ wind speed $\left(\mathrm{m} \mathrm{s}^{-1}\right) ; X_{2}=$ humidity; $X_{3}=$ ambient temperature $\left({ }^{\circ} \mathrm{C}\right) ; X_{4}=$ mid-season dummy variable; $X_{5}=$ grass percentage of biomass; $X_{6}=$ early-season dummy variable; $X_{7}=$ annual and perennial binary variable

\begin{tabular}{|c|c|c|c|c|c|c|c|}
\hline Model & $\mathbf{R}$ & $R^{2}$ adj & $\mathrm{F}$ & Sig $F$ & Power & $\# \chi$ & Model variables and constants \\
\hline Enter & 0.481 & 0.093 & 1.677 & 0.143 & 0.233 & 7 & \\
\hline Backward & 0.309 & 0.075 & 4.751 & 0.035 & 0.475 & 1 & $Y=2.20+0.17 X_{1}$ \\
\hline Forward & 0.238 & 0.047 & 5.711 & 0.019 & 0.561 & 1 & $Y=2.20+0.17 X_{1}$ \\
\hline
\end{tabular}


Table 7 Back-fire regression model statistics from the seasonal fire intensity field study conducted in Mali, West Africa, from 2014 to 2016. F and Sig F are F-test and significance, respectively, and $\# \chi$ is the number of independent variables in the model. $Y=\log$ fireline intensity; $X_{1}=$ wind speed $\left(\mathrm{m} \mathrm{s}^{-1}\right) ; X_{2}=$ humidity; $X_{3}=$ ambient temperature $\left({ }^{\circ} \mathrm{C}\right) ; X_{4}=$ mid-season dummy variable; $X_{5}=$ grass percentage of biomass; $X_{6}=$ early-season dummy variable; $X_{7}=$ annual and perennial binary variable

\begin{tabular}{|c|c|c|c|c|c|c|c|}
\hline Model & $\mathbf{R}$ & $R^{2}$ adj & $\mathbf{F}$ & Sig $F$ & Power & $\# \chi$ & Model variables and constants \\
\hline Enter & 0.620 & 0.282 & 3.756 & 0.003 & 0.710 & 7 & \\
\hline Backward & 0.598 & 0.301 & 6.270 & $<0.001$ & 0.854 & 4 & $Y=2.47+0.14 X_{1}-0.02 X_{2}-0.23 X_{6}-0.34 X_{4}$ \\
\hline Forward & 0.514 & 0.233 & 8.454 & 0.001 & 0.850 & 2 & $Y=2.848-0.02 X_{2}-0.21 X_{7}$ \\
\hline
\end{tabular}

shared by the Forward model, while the Forward model added only one other variable, the annual and perennial binary. It should be noted that the annual and perennial binary variable reflects the shift from shorter vegetation, predominantly annuals, to taller perennials. As such, this variable reflects the influence of moisture content (perennial hold moisture longer) and fuel structure (perennial grasses in this study region are primarily bunch grasses with fewer stems per unit area than the annual grasses). As noted, a decline in grass as a percentage of total biomass reflects the increase in leaf litter, which affects fuel connectivity as well as fuel structure.

\section{Discussion}

In all, we found that back-fires, as practiced by Malian land managers, produce fireline intensities that more strongly relate to variables pertaining to ambient air conditions and the state of the fuels, than do head-fires. Their activities appear timed for relatively optimal conditions for fire management. Head-fires, not commonly or deliberately used by land managers, are less predictable. They are, however, widely described in the literature. As such, we conducted a large number of them for comparison. The models produced here by automatic selection underscore the differences between head-fires and back-fires; the models created with all 97 complete records produced generally weak results as they blend together fires from entirely different fire practice populations.

We found that the characteristics of experimental fires varied by season. As expected, mean visual efficiency and mean combustion completeness increased as the dry season progressed. We also found that the highest intensity fire occurred in the EDS (in a dense field of dry annual grasses, with a head-fire). While early fires are often thought to be less intense (e.g., Govender et al. 2006; Smit et al. 2016), other studies have also found that EDS fires can be very intense if burned with a head wind (Cook et al. 2015). Our study found that EDS fires also exhibited the greatest variation, probably due to the type of grass burned. While the minimum intensity value increased from
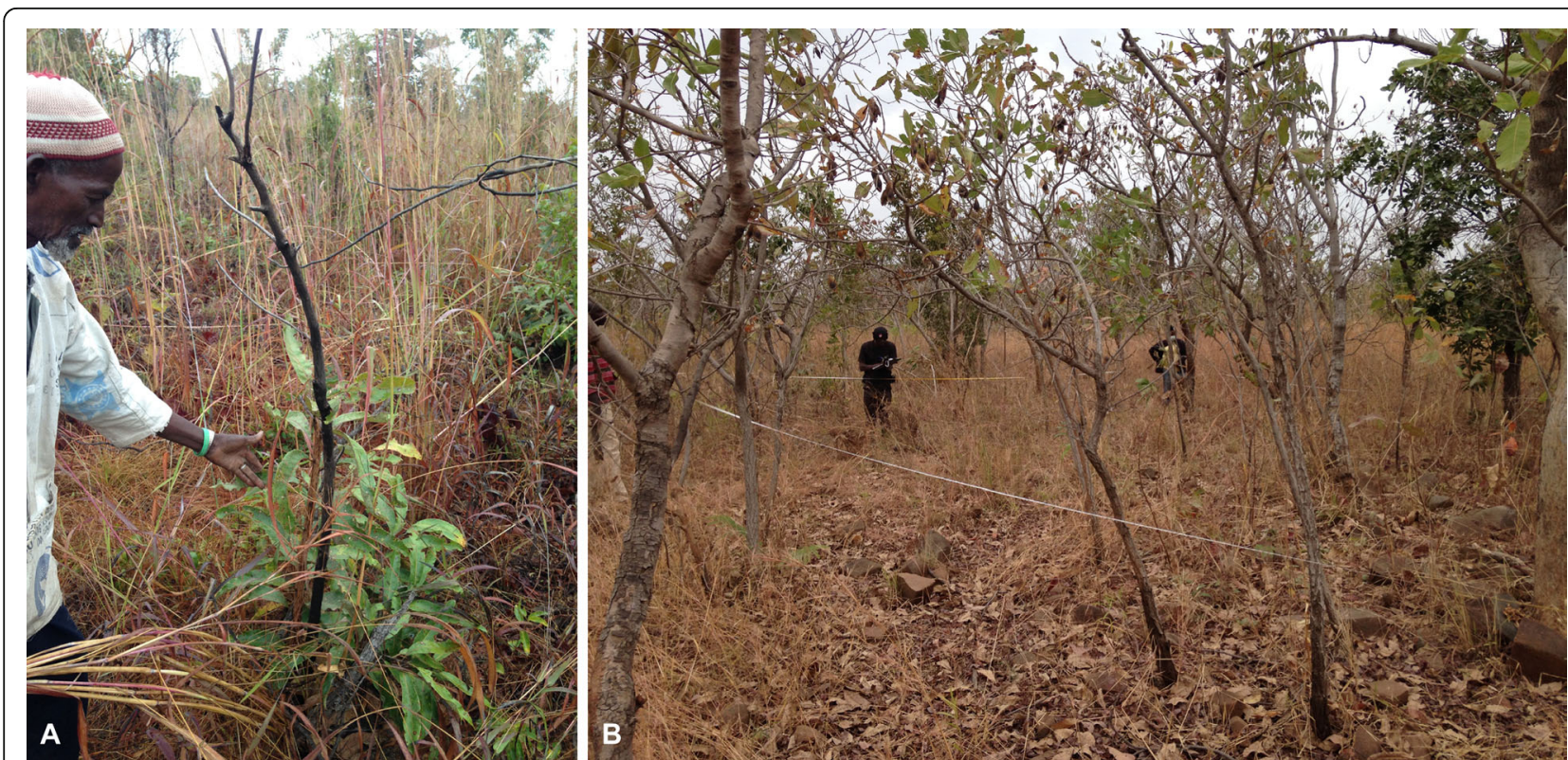

Fig. 3 Seasonal fire intensity experimental plot in Tabou Village, Mali, Africa, in 2016. (A) A perennial grassland in Tabou Village, Mali, that was still too moist to carry a fire in early January, and (B) heavy leaf litter in a well trampled savanna. Photographer credit: Paul Laris 
the beginning to the end of the dry season, the maximum intensity value progressively decreased. In addition, while fires tend to become more intense as the dry season progresses, they also become more uniform. As expected, the LDS had the highest mean intensity, $236.8 \mathrm{~kW} \mathrm{~m}^{-1}$. What is surprising was that the MDS fires had the lowest mean intensity value, $212.0 \mathrm{~kW} \mathrm{~m}^{-1}$, with the EDS mean intensity falling between them at $223.8 \mathrm{~kW} \mathrm{~m}^{-1}$.

Several factors may explain the observed variation in intensity values and especially the lower MDS values. First, the drop in the middle-season fire-spread rate and scorch height is possibly explained by the fact that these fires burned grasses that had not fully cured (we some plots with over $25 \%$ moisture content as a result); and second, the fuel structure also varied by season and grass type. Not all grass types can burn during the early months of the fire season due to the higher levels of fuel moisture. For example, deep-rooted perennial grasses such as Andropogon gayanus will not burn early (especially with a back-fire) as they cure slowly (Fig. 3). As such, the early season contains little data on fires in perennial grasslands, while the middle season contains a greater number of data from fires in moist grasses (note that this is in accordance with local fire-setting practices). These same perennial grasses, which are too moist to carry a fire during the early season, are normally quite dry when burned in the late fire season. Indeed, we found that the mean intensity for perennial grasses was lower than that for annuals (207.1 to $246.7 \mathrm{~kW} \mathrm{~m}^{-1}$ ). We reiterate that, when asked, the majority of West African fire starters indicate that they seek to set back-fires to grasses "just dry enough to burn" in the afternoons when temperatures and winds are falling and humidity is rising, producing the relatively lower fire intensities recorded in our study. As noted, there is also a shift in fuel load over the course of the fire season as leaf litter increases. Greater leaf litter improves the connectivity of the fuel in certain environments, such as for bunch grasses, while also altering fuel structure (Fig. 3). The spacing between bunch grasses, especially those in wellgrazed areas, can be quite high, effecting fuel continuity and burning, especially under low wind conditions. In addition, trampling and grazing can cause important changes to fuel structure (Kone 2013) and these may slow fire spread rate. Finally, annual grasses tend to bend over and flatten as they die (Fig. 4). These changes in fuel composition and structure may change fire behavior in part because more tightly compacted fuels restrict the flow of oxygen. These factors can also improve fuel connectivity, which can increase burn completeness and combustion completeness even if they burn more slowly and thus with lower intensity even as fire efficiency and combustion completeness increase.

We found fire intensity was weakly, but significantly, correlated to combustion completeness although, as expected, intensity was correlated more strongly and significantly to scorch height and visual efficiency. This disparity could indicate that some fires had a high rate of spread but a lower amount of biomass consumption, or inversely, that slower fires were able to consume a greater amount of biomass due to their longer residence time. Observations in the field bear this out, especially in the case in which there was significant leaf litter in the fuel mix.

Byram's fire intensity values were similar to those from several other studies. Our fires had intensity values between 12 to $1400 \mathrm{~kW} \mathrm{~m}^{-1}$, which compares somewhat

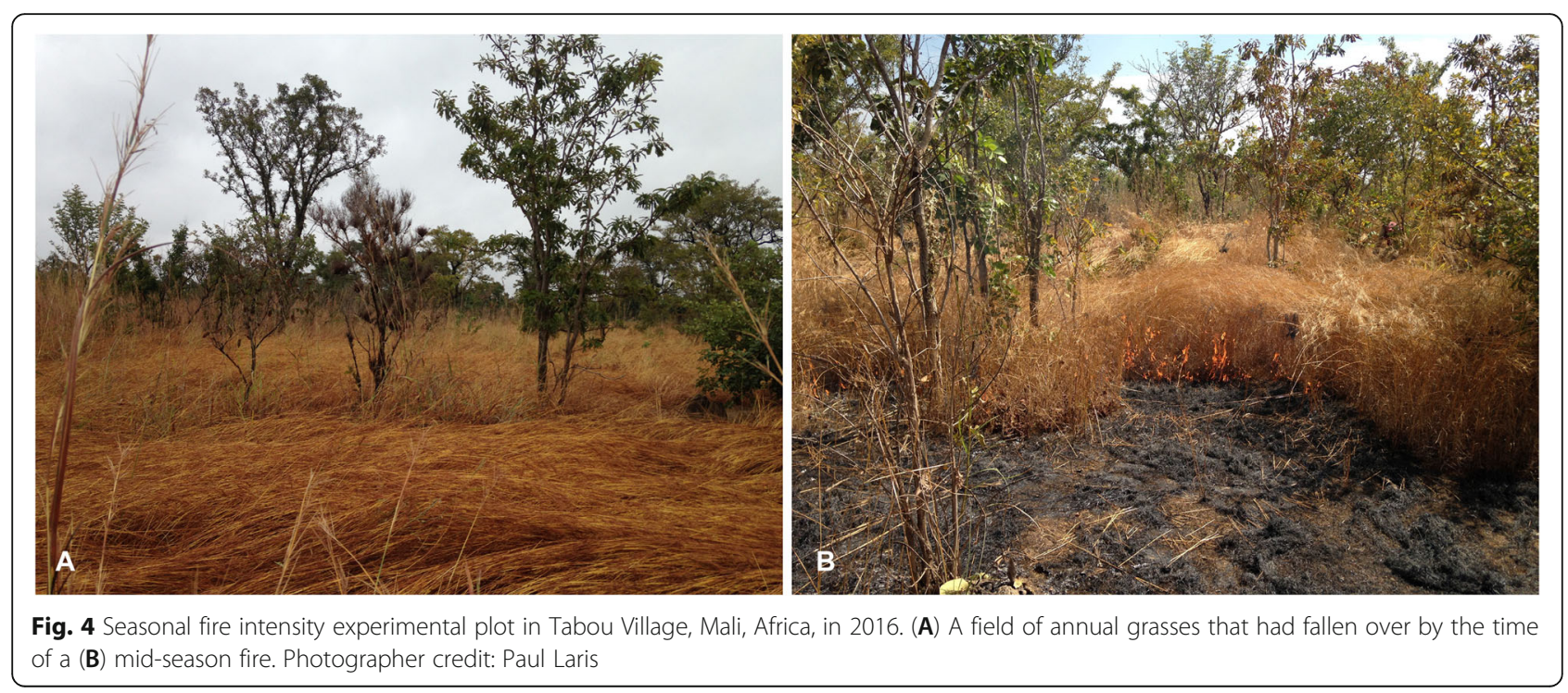


Table 8 Intensity values ( $\mathrm{kW} \mathrm{m}^{-1}$ ) of head- and back-fires for all plots from the seasonal fire intensity field study conducted in Mali, West Africa, from 2014 to 2016 (Mali), and those from Trollop et al. (2002) for the Eastern Cape Province of South Africa (South Africa)

\begin{tabular}{|c|c|c|c|c|c|}
\hline \multirow[b]{2}{*}{ Location } & \multirow{2}{*}{$\begin{array}{l}\text { Fire } \\
\text { type }\end{array}$} & \multirow[b]{2}{*}{$n$} & \multicolumn{3}{|c|}{ Intensity $\left(\mathrm{kW} \mathrm{m}^{-1}\right)$} \\
\hline & & & Mean & Minimum & Maximum \\
\hline \multirow[t]{2}{*}{ Mali } & Head-fire & 47 & $342.3 \pm 259$ & 46.6 & 829.6 \\
\hline & Back-fire & 50 & $120.4 \pm 72$ & 10.8 & 460.3 \\
\hline \multirow[t]{2}{*}{ South Africa } & Head-fire & 10 & $1359 \pm 327$ & 338 & 3557 \\
\hline & Back-fire & 9 & $194 \pm 18$ & 87 & 268 \\
\hline
\end{tabular}

favorably to the seasonal variation of 25 to $5300 \mathrm{~kW} \mathrm{~m}^{-1}$ in Zambian Miombo (Hoffa et al. 1999). In the Guinea savanna of West Africa, N'Dri et al. (2018) found intensity values similar to those on the high end of our study $\left(3920 \mathrm{~kW} \mathrm{~m} \mathrm{~m}^{-1}\right.$ and $3134 \mathrm{~kW} \mathrm{~m}^{-1}$, for MDS and LDS fires, respectively). The difference in their intensity values derives largely from a difference in fire spread rates, which varied from $0.14 \mathrm{~m} \mathrm{~s}^{-1}$ and $0.12 \mathrm{~m} \mathrm{~s}^{-1}$ for mid- and late-season fires, respectively, but only $0.04 \mathrm{~m} \mathrm{~s}^{-1}$ for early dry-season fires. N'Dri and colleagues found that fuel moisture was a key determinant of their study findings (although it should be stressed that their recorded wind speeds were significantly higher than ours, perhaps due to the morning burn time selected). We suspect that a key difference in findings between these two West African studies derives from the fact that our fires were set under conditions of lower wind speeds and that the grass types burned varied by season (as did moisture levels), both in accordance with local practices.

In one of very few studies to include MDS fires, research in the Cerrado of Brazil by Rissi et al. (2017) found no significant differences in intensity or flame height across the early, middle, and late fire seasons for head-fires. In one of few studies to distinguish between head- and back-fires in Africa, Trollope et al. (2002) calculated mean head-fire intensity values of $1359 \mathrm{~kW} \mathrm{~m}^{-1}$ (higher than our values of $342.3 \mathrm{~kW} \mathrm{~m}^{-1}$ ) and back-fire values of $194 \mathrm{~kW} \mathrm{~m}^{-1}$ closer to our value of $120.4 \mathrm{~kW} \mathrm{~m}^{-1}$ (Table 8 ). While biomass values were similar (mean of $3847 \mathrm{~kg} \mathrm{ha}^{-1}$ ) for Trollope et al. (2002) and seasonal means of 3900 to $4530 \mathrm{~kg} \mathrm{ha}^{-1}$ for Mali), Trollope's study had higher mean wind speeds of $2.6 \mathrm{~m} \mathrm{~s}^{-1}$ (0.3 to $\left.6.7 \mathrm{~m} \mathrm{~s}^{-1}\right)$-about double ours, which drove the higher intensity values. Indeed, in a separate study, Trollope (1987) recorded fire spread rates of 0.11 to $0.36 \mathrm{~m} \mathrm{~s}^{-1}$ compared with our much lower seasonal mean

\footnotetext{
${ }^{3}$ Note that fuel loads on protected plots burned annually were nearly double those on the unprotected plots used in this study. Our values were also similar to values from the unprotected areas used in research by Savadogo et al. (2007) in Senegal.
}

rates of 0.024 to $0.034 \mathrm{~m} \mathrm{~s}^{-1}$. Beaufait (1965) concluded that wind speeds from 0.0 to $3.6 \mathrm{~m} \mathrm{~s}^{-1}$ increased the rate of spread of head-fires exponentially (but had no effect on rate of spread of back-fires); thus, wind likely explains the differences in head-fire intensity between the studies. It is worth noting, however, that it has been well documented that fire intensity in savannas have a potential 100-fold range, primarily because of the large variation of possible spread rates (Stocks et al. 1997).

Our study values are similar to those from RussellSmith et al. (2003) as well. They found that mean fire intensities ranged from $421 \mathrm{~kW} \mathrm{~m}^{-1}$ for early fire treatments and $1177 \mathrm{~kW} \mathrm{~m} \mathrm{~m}^{-1}$ for late ones in a wooded savanna in Australia. They suggested that their lowerthan-expected intensity values were a result of the relatively small size of their treatment plots because, they argue, this precluded the attainment of maximum forward rates of spread. It is important to note that, although the size of test plots may have affected the spread rate of head-fires under high wind conditions, plot size is unlikely to affect the speed of head-fires under low winds or that of back-fires, which burn slowly and develop a front in a short distance. In our experiments, the speed of the flaming fronts was not observed to change much except in the rare occasion of a headfire set under high wind conditions. Our observations conform with those of Cheney and Gould (1995: 246) who concluded, "The head fire width required for fires to approach their potential quasi-steady rate of forward spread increases with increasing wind speeds. As such, fires under weak wind conditions have a narrow fireline that is faster to develop." We also observed in the field that, under low wind conditions, fires were quick to develop a quasi-steady fire front.

Lastly, it is critical to note that, with the exception of plot size, all of the other relevant factors noted above reflect differences resulting from our use of working landscapes as opposed to reserves devoid of indigenous people. People set fires in West Africa later in the day (resulting in less hazardous fire weather) and they set predominantly back-fires (which burn slowly and do not require large areas to develop). In addition, fuel loads and structure are modified by animal grazing and trampling, and this likely explains some of the differences in fire intensity values. ${ }^{3}$ As Cheney et al. (1993) found, heterogeneity caused by animal grazing and trampling significantly reduces fire spread rate. Finally, in terms of plot size, it should be noted that West African fires notoriously burn small and fragmented patterns especially when set early (Laris 2011). In summary, although our values are lower than those found for some other studies, they may well reflect more accurately the intensity of fires set by rural Africans as our study was designed to replicate the most common practice of rural Malians in 
working landscapes, which is in stark contrast with most other studies, which typically sought to maximize fire intensity by setting head-fires under windy conditions. Moreover, recent remotely sensed data on fire radiative power finds that the values in Africa are trending downward, most likely the result of increasing land use pressure and reduced biomass available for burning.

What are the implications of our results for the relationship between fire intensity and tree death or topkill? As noted above, Trollope et al. (2002) argued that trees are sensitive to increasing fire intensities because their growing points are exposed to the release of heat energy, especially in the case of head-fires. Indeed, our fieldwork on scorch heights found that many small trees were scorched at a height of 1.5 meters, often killing the stem and causing a basal resprout (P. Laris, University of California, Long Beach, USA; unpublished data). Our study found one caveat to Trollope's point, and that is that different savanna grass species often grow to very different heights even in the same landscape. For example, perennial grasses can be two to three times taller than annuals (over $3 \mathrm{~m}$ in our study area, compared with $1.5 \mathrm{~m}$ for annuals). In addition, as noted, fuel structure changes over the course of the season. These factors likely affect flame heights as well.

Lastly, it is important to remember that higher fire intensity is but one factor that could cause later dryseason fires to be more damaging to trees than earlyseason fires. As West (1965) noted long ago, trees are more heat and moisture stressed later in the dry season. As such, late dry-season fires may very well be more damaging to small trees and seedlings, but for reasons that have less to do with fire intensity itself than with its interaction with the other stresses acting on trees later in the season.

\section{Conclusion}

This study found that wind direction has a greater effect on fire intensity in working West African savanna landscapes than fire season. Our results showed that headfires have a higher average intensity and much greater variation than back-fires. In head-fires, only wind speed among the evaluated variables explained intensity when the fire and the wind are traveling in the same direction. For back-fires, timing within the fire season, as represented by the two season dummy variables, emerged as a major explanatory variable in Backward regression modeling, as well as wind speed and humidity conditions as they shifted within the season. Forward modeling of back-fires found humidity and the annual and perennial binary to be significant explanatory variables. The statistically significant relationship between seasonal timing, grass variables, and back-fire intensity aligned with previous savanna research (Trollope et al. 2002).
The concept of fire season is deeply entrenched in the African fire science and policy literature (e.g., Laris and Wardell 2006; Furley et al. 2008; Laris et al. 2017). As such, our results have important implications for fire policy because, in many savannas, fire intensity is considered to be a function of fire season, with later fires burning more intensely and causing more damage to juvenile trees than earlier ones (e.g., Scholes and Walker 1993; Sankaran et al. 2004; Staver et al. 2011). Our study found that, while late-season fires did have the highest intensity, mid-season fires, set under typical burning practices, had the lowest intensity values of all fires. It is important to note that burning in the West Africa region is most common in the mid season. Perhaps more importantly, our research found that head-fires have nearly three times the intensity of back-fires, while intensity varied much less by season; however, fire policies in the region rarely mention fire type. Critically, there have been few efforts to determine the amount of African landscape annually burned by head- or back-fires, and too few field studies have involved back-fires. Future efforts should focus on estimating the amount of area burned as head- or back-fire using remotely sensed imagery and models.

Our study finds that fire intensity values dip during the middle fire season, which is the time of peak burning in West African savannas. Moreover, intensity values found in our analysis are an order of magnitude less than those reported in some other studies. The key reasons derive largely from the fact that our research aimed to investigate realistic fire conditions on working lands as opposed to the ideal ones commonly used in other studies. We conclude that more research is needed to establish the relationship between fire intensity, combustion completeness, and ecological responses, such as tree death or top-kill, in working landscapes. It is unknown whether rate of tree survival on such working lands also varies from the rates found in previous work. Given the inconsistencies between intensity values found in prior research and in this analysis, it would be reasonable to postulate that ecological effects of fires would also diverge from those studies.

\footnotetext{
Acknowledgements

The authors thank the participation of the people of Tabou and Faradiele villages for their assistance in the field and for their hospitality. Thank you as always to F. Camara for his participation and leadership in the field. The research was funded by NSF grant \#1313820.
}

\section{Authors' contributions}

$\mathrm{RJ}$ performed the analysis of the data and wrote the Master's thesis that was the basis for the paper. PL was principal investigator on the project and supervised all aspects of the research. He revised the thesis into manuscript form. MK was involved in the fieldwork and the gathering and cleaning of all data. FD was head of the field research team and advisor on the field 
experiments. CR was advisor on data analysis and statistics. All authors read and approved the final manuscript.

\section{Funding}

This study was funded by the National Science Foundation. Funds were used to collect and analyze all data and to write the Master's thesis on which this paper is based.

\section{Availability of data and materials}

Data for this study will be posted on our website as per agreement with the National Science Foundation: http://www.cla.csulb.edu/departments/ geography/savannalabo/

\section{Ethics approval and consent to participate}

Not applicable.

\section{Consent for publication}

Photos were taken by the lead authors, consent to publish is given Facourou Camara gives his consent to use his image in Fig. 3.

\section{Competing interests}

The authors declare that they have no competing interests.

\section{Author details}

${ }^{1}$ Geography Department, California State University Long Beach, 1250 Bellflower Boulevard, Room PH1-210, Long Beach, California 90840, USA. Université Félix Houphouët-Boigny, Geography, BP V34, Abidjan, République de Côte d'Ivoire. ${ }^{3}$ Institut Polytechnique Rural de Formation et de Recherché Appiquée de Katibougou (IPR/IFRA), Bamako, Mali.

Received: 4 May 2020 Accepted: 21 October 2020

Published online: 07 December 2020

\section{References}

Afolayan, T., and S. Ajayi. 1979. Reasons for further burning experiments in West African savanna woodland. Commonwealth Forestry Review 58 253-265.

Aubréville, A. 1953. Les expériences de reconstitution de la savane boisée en Cote d'Ivoire [Experiments with the restoration of the wooded savanna in the Ivory Coast]. Bois et Forets des Trop 32: 4-10

Austin, P.C., and E.W. Steyerberg. 2015. The number of subjects per variable required in linear regression analyses. Journal of Clinical Epidemiology 68: 627-636. https://doi.org/10.1016/j.jclinepi.2014.12.014

Beaufait, W.R. 1965. Characteristics of backfires and headfires in a pine needle fue bed. Ogden: USDA Forest Service, Intermountain Forest and Range Experiment Station, Research Paper INT-39.

Biggs, R., H.C. Biggs, T.T. Dunne, N. Govender, and A.L.F. Potgieter. 2003. Experimental burn plot trial in the Kruger National Park: History, experimental design and suggestions for data analysis. Koedoe 46: 1-15. https://doi.org/10. 4102/koedoe.v46i1.35.

Brookman-Amissah, J., J. Hall, M. Swaine, and J. Attakorah. 1980. A re-assessment of a fire protection experiment in north-eastern Ghana. Journal of Applied Ecology 17: 85-99. https://doi.org/10.2307/2402965.

Byram, G.M. 1959. Combustion of forest fuels. In Forest fire: Control and use, ed. K. P. Davis, 61-89. New York: McGraw-Hill.

Charnley, S., T.E. Sheridan, and G.P. Nabhan, eds. 2014. Stitching the west back together: Conservation of working landscapes. Chicago: The University of Chicago Press. https://doi.org/10.7208/chicago/9780226165851.001.0001.

Cheney, N.P. 1981. Fire behaviour. In Fire and the Australian biota, ed. A.M. Gill, R. H. Groves, and I.R. Noble, 151-175. Canberra: Australian Acad. Sci.

Cheney, N.P., and J.S. Gould. 1995. Fire growth to a quasi-steady rate of forward spread. International Journal of Wildland Fire 5: 237-247. https://doi.org/10. 1071/WF9950237

Cheney, N.P., J.S. Gould, and W.R. Catchpole. 1993. Influence of fuel, weather and fire shape variables on fire spread. International Journal of Wildland Fire 3: 144. https://doi.org/10.1071/WF9930031.

Cheney, N.P., J.S. Gould, and W.R. Catchpole. 1998. Prediction of fire spread in grasslands. International Journal of Wildland Fire 8: 1-15. https://doi.org/10. 1071/WF9980001

Chidumayo, E. 1997. Effects of accidental and prescribed fires on Miombo woodland, Zambia. Commonwealth Forestry Review 74: 288-292.
Cook, G.D., A.C. Liedloff, and B.P. Murphy. 2015. Predicting the effects of fire management on carbon stock dynamics using statistical and processbased modelling. In Carbon accounting and savanna fire management, ed. J. Russell-Smith, B. Murphy, A. Edwards, and C.P. Meyer, 295-320. Victoria: CSIRO.

Devine, A.P., I. Stott, R.A. McDonald, and I.M.D. Maclean. 2015. Woody cover in wet and dry African savannas after six decades of experimental fires. Journal of Ecology 2015 (103): 473-478. https://doi.org/10.1111/1365-2745.12367.

Duvall, C.S. 2011. Biocomplexity from the ground up: Vegetation patterns in a west African savanna landscape. Annals of the Association of American Geographers 101: 497-522. https://doi.org/10.1080/00045608.2011.560061.

Eldroma, E.L. 1984. Effects of burning and grazing on the productivity and number of plants in the Queen Elizabeth National Park, Uganda. African Journal of Ecology 22: 165-174. https://doi.org/10.1111/j.1365-2028.1984.tb00691.x.

Faul, F., E. Erdfelder, A. Buchner, and A.-G. Lang. 2009. Statistical power analyses using G*Power 3.1: Tests for correlation and regression analyses. Behavior Research Methods 41: 1149-1160. https://doi.org/10.3758/BRM.41.4.1149.

Furley, P.A., R.M. Rees, C.M. Ryan, and G. Saiz. 2008. Savanna burning and the assessment of long-term fire experiments with particular reference to Zimbabwe. Progress in Physical Geography 32: 611-634. https://doi.org/10. 1177/0309133308101383.

Govender, N., W.S. Trollope, and B. Van Wilgen. 2006. The effect of fire season, fire frequency, rainfall and management on fire intensity in savanna vegetation in South Africa. Journal of Applied Ecology 43: 748-758. https://doi.org/10. 1111/j.1365-2664.2006.01184.x

Hammer, Ø., D.A.T. Harper, and P.D. Ryan. 2001. PAST: Paleontological statistics software package for education and data analysis. Palaeontologia Electronica 4 (1): 9 http://folk.uio.no/ohammer/past/.

Henry, C. 2011. An integrated approach to estimating groundwater storage, variability and recharge in Southern Mali, Africa. M.Sc Thesis. Canada: Department of Earth Sciences, Simon Fraser University.

Higgins, S., W. Bond, E. February, A. Bronn, V. Euston-Brown, B. Enslin, N. Govender, L. Rademan, S. O'Regan, A.L. Potgieter, S. Scheiter, R. Sowry, L. Trollope, and W.S.W. Trollope. 2007. Effects of four decades of fire manipulation on woody vegetation structure in savanna. Ecology 88: 11191125. https://doi.org/10.1890/06-1664.

Hoffa, E.A., R.H. Wakimoto, D.E. Ward, W.M. Hao, and R.A. Susott. 1999. Seasonality of carbon emissions from biomass burning in a Zambian savanna. Journal of Geophysical Research 104: 13,841-13,853. https://doi.org/10.1029/ 1999JD900091.

Kone, M. 2013. Up in smoke: Biomass burning and atmospheric emissions in the Sudanian Savanna of Cote D'lvoire. Urbana: Dissertation. University of Illinois.

Laris, P. 2002. Burning the seasonal mosaic: Preventive burning strategies in the wooded savanna of Southern Mali. Human Ecology 30: 155-186. https://doi. org/10.1023/A:1015685529180.

Laris, P. 2011. Humanizing savanna biogeography: Linking human practices with ecological patterns in a frequently burned savanna of southern Mali. Annals of the Association of American Geographers 101: 1067-1088. https://doi.org/ 10.1080/00045608.2011.560063.

Laris, P., S. Dadashi, A. Jo, and S. Wechsler. 2016. Buffering the savanna: Fire regimes and disequilibrium ecology in West Africa. Plant Ecology 217: 583596. https://doi.org/10.1007/s11258-016-0602-0

Laris, P., M. Kone, S. Dadashi, and F. Dembele. 2017. The early/late fire dichotomy: Time for a reassessment of Aubreville's savanna fire experiments. Progress in Physical Geography 41: 68-94. https://doi.org/10.1177/0309133316665570.

Laris, P., and D.A. Wardell. 2006. Good, bad or "necessary evil?": Reinterpreting the colonial burning experiments in the savanna landscapes of West Africa. Geographical Journal 172: 217-290. https://doi.org/10.1111/j.1475-4959.2006.00215X.

Le Page, Y, O. Duarte, P. Jonsson, and J. Pereira. 2010. Seasonality of Vegetation Fires as Modified by Human Action: Observing the. Deviation from EcoClimatic Fire Regimes. Global Ecology and Biogeography 19:575-88.

Louppe, D., N. Oattara, and A. Coulibaly. 1995. The effects of brush fires on vegetation: The Aubreville Fire Plots after 60 years. Commonwealth Forestry Review 74: 288-291.

McArthur, A.G. 1967. Fire behaviour in eucalypt forests, 25. Canberra. Leaflet Number 107: Commonwealth of Australia Forest and Timber Bureau.

McDonald, J.H. 2014. Handbook of biological statistics. 3rd ed. Baltimore: Sparky House Publishing.

N'Dri, A.B., T.D. Soro, J. Gignoux, et al. 2018. Season affects fire behavior in annually burned humid savanna of West Africa. Fire Ecology 14. https://doi. org/10.1186/s42408-018-0005-9. 
Ramsay, J., and R. Rose-Innes. 1963. Some observations on the effects of fire on the Guinea savanna vegetation of northern Ghana over a period of eleven years. African Soils 8: 41-85.

Rissi, M.N., M.J. Baeza, E. Gorgone-Barbosa, T. Zupo, and A. Fidelis. 2017. Does season affect fire behaviour in the Cerrado? International Journal of Wildland Fire 26: 427-433. https://doi.org/10.1071/WF14210.

Russell-Smith, J., P.J. Whitehead, G.D. Cook, and J.L. Hoare. 2003. Response of Eucalyptus dominated savanna to frequent fires: lessons from Munmarlary, 1973-1996. Ecological Monographs 73: 349-375. https://doi.org/10.1890/01-4021.

Ryan, C.M., and M. Williams. 2011. How does fire intensity and frequency affect miombo woodland tree populations and biomass? Ecological Applications 21: 48-60. https://doi.org/10.1890/09-1489.1.

Sankaran, M., J. Ratnam, and N.P. Hanan. 2004. Tree-grass coexistence in savannas revisited: insights from an examination of assumptions and mechanisms invoked in existing models. Ecology Letters 7: 480-490. https://doi.org/10. 1111/j.1461-0248.2004.00596.x.

Savadogo, P., D. Zida, L. Sawadogo, et al. 2007. Fuel and fire characteristics in savanna-woodland of West Africa in relation to grazing and dominant grass type. International Journal of Wildland Fire 16: 531-539. https://doi.org/10. 1071/WF07011.

Scholes, R., and B. Walker. 1993. An African savanna: Synthesis of the Nylsyley study. Cambridge: Cambridge University Press. https://doi.org/10.1017/ CBO9780511565472.

Smit, I.P.J., G.P. Asner, N. Govender, N.R. Vaughn, and B.W. van Wilgen. 2016. An examination of the potential efficacy of high-intensity fires for reversing woody encroachment in savannas. Journal of Applied Ecology 53: 1623-1633. https://doi.org/10.1111/1365-2664.12738.

Staver, A.C., S. Archibald, and S. Levin. 2011. The global extent and determinants of savnna and forest as alternative states. Science 334: 230-232. https://doi. org/10.1126/science.1210465.

Stocks, B.J., B.W. Van Wilgen, and W.S.W. Trollope. 1997. Fire behaviour and the dynamics of convection columns in African savannas. In Fire in Southern African savannas: Ecological and atmospheric perspectives, ed. B.W. Van Wilgen, M.O. Andreae, G.J. Goldammer, and J.A. Lindesay, 47-55. Johannesburg: Wits University Press.

Trapnell, L.C.G. 1959. Ecological results of woodland burning experiments in Northern Rhodesia. Journal of Ecology 47: 129-168. https://doi.org/10.2307/2257252

Trollope, W.S.W. 1987. Effect of season of burning on grass recovery in the false thornveld of the eastern cape. Journal of the Grassland Society of Southern Africa 4: 74-77. https://doi.org/10.1080/02566702.1987.9648074.

Trollope, W.S.W., L.A. Trollope, and D.C. Harnett. 2002. Fire behaviour a key factor in the fire ecology of African grasslands and savannas. In Forest fire research and wildland fire safety, ed. D.X. Viegas, 1-15. Rotterdam: Millpress.

Viney, N.R. 1991. A review of fine fuel moisture modelling. International Journal of Wildland Fire 1: 215-234. https://doi.org/10.1071/WF9910215.

West, O. 1965. Fire in vegetation and its use in pasture management with specia reference to tropical and subtropical Africa. In Mem. Pub. Commonwealth. Agric. Bur., Farnham Royal, Bucks., England, 1.

Williams, R.J., G.D. Cook, A.M. Gill, and P.H.R. Moore. 1999. Fire regime, fire intensity and tree survivals in a tropical savanna in northern Australia. Austral Ecology 24: 50-59. https://doi.org/10.1046/j.1442-9993.1999.00946.x.

Williams, R.J., A.M. Gill, and P.H. Moore. 1998. Seasonal changes in fire behavior in a tropical savanna in northern Australia. International Journal of Wildland Fire 8: 227-239. https://doi.org/10.1071/WF9980227.

\section{Publisher's Note}

Springer Nature remains neutral with regard to jurisdictional claims in published maps and institutional affiliations.

\section{Submit your manuscript to a SpringerOpen ${ }^{\circ}$ journal and benefit from:}

- Convenient online submission

- Rigorous peer review

- Open access: articles freely available online

- High visibility within the field

- Retaining the copyright to your article

Submit your next manuscript at $\boldsymbol{\nabla}$ springeropen.com 